\title{
Women as Their Own Worst Enemies: Rewriting the Stepmother and Mother-In-Law Archetypes in Adimora-Ezeigbo'sRoses and Bullets
}

\author{
Anthonia Makwemoisa Yakubu
}

\begin{abstract}
The paper carries out an examination of the common saying that women are their own worst enemies, analysing the intimidating statures of two social figures - the stepmother and the mother-in-law - and the complexities that exist in the relationships these have with 'lesser' women. It argues that even though the novel re-inscribes the general myth about these two archetypal types, the author also throws up contrastive characters that reflect the balance in all human relationships, as no society is made up of entirely good (roses) or bad (bullets) people. Applying the feminist theory of subjectivity, the paper critiques gender relations that demonise one sex in favour of the other, and the deliberate righting of this myth through positive character portrayals of women.
\end{abstract}

\section{Introduction}

Women and men live, for the most part, in a patriarchal environment. This environment thrives on the belief that women are unequal to men biologically and psychologically. The inequality is then translated to mean that the female sex is subservient to the male. This biased view of the subservient nature of women is also maintained through social conditioning. One of the most important aspects of the social conditioning is that women do not like and cannot trust one another. This belief is embedded in folktales, myths, proverbs and sayings that have become common over the years. It is unconsciously communicated in women's relationship with other women who are not their equal on the social ladder; or who are real or potential threats/competitors for the small space they enjoy in the patriarchal order.

Men create some of these attitudes and beliefs but they are sustained, nurtured, and recreated by women. The injurious lessons affirmed by these stories are that women are not trustworthy. They cannot trust themselves; they are their own worst enemies. When women do not trust themselves, they automatically transfer their trust and allegiance to the male folk (Koroye \& Anyadike, 2004). The manifestations of this are varied, but the most common are co-wife rivalry, mother-in-law/daughter-in-law rivalry, stepmother/step-children discord and wife/sisters-in-law rivalry. When women spend a significant proportion of their time and energy fighting one another, they become easy targets of the machinations of patriarchy (Ezeigbo, 1993; Lashgari, 1995). The distrust among women is also reflected in the metaphysical realm. A few examples would suffice.

The Igbo generally believe in a supreme deity called Chineke (the creator God) or Chukwu (the Great God). They also believe and pay homage to some 'smaller' gods who act as intermediaries between them and Chukwu. Some of these gods are Amadi-Oha (the god of thunder and lightning), Anyanwu (the god of the sun), Igwe (the sky god and husband to Ala), and Ala (the earth goddess). Of all these gods, cutting across the different communities of the Igbo, the earth goddess, Ala, is the most revered. According to Ilogu (1985:35):

Ala is the most important deity in Igbo social life. She is the guardian of morality, the controller of the minor gods... Because of her importance in ensuring health, agricultural fortune and hunting successes, she is well known all over Igbo land.

However, the reverence given to Ala is not extended to girl children and women. Most times, these goddesses are adorned and addressed in masculine terms, thereby transcending their physical feminine bodies and placing a barrier (distrust), to a robust relationship with the women folk.

In Yoruba traditional belief, there is Aje, the goddess of wealth and fertility. Prayers and sacrifices are offered to her to grant their requests of having money/more money, to be wealthy, and to prosper in their businesses. The women, however, owe more allegiance to her as she is believed to be the controller of the market economy. Ironically, in spite the high number of women in the market economy, the bulk of the wealth remains with their men, who also control the political terrain. Aje's presence and power do not translate to greater financial autonomy to the generality of her female subjects. Among the Ondo, a popular Aje myth exists about the 
introduction of cowries into the market economy. Beyond its face value, the myth encodes the complexities of social relations amongst women:

After the first market of the Ondo had been established, the people were faced with the problem of which form of exchange to use. It was decided that Olodumare (the Supreme deity) should be met and the problem be presented to Him for solution. Olodumare was met and the matter was discussed. He instructed that a ritual be done with a mother hen, a he-goat and a frog. Thereafter the contingent should meet with Aje. The ritual sacrifice was to protect the contingent from death or any danger on their way to Aje's house. But then, in spite of the rituals, there were no human volunteers to meet with Aje. After a lot of persuasion and several days of waiting, the vulture bird agreed to go. Two women also volunteered. However, only the vulture bird eventually met with Aje; the women stood at a distance. On getting to Aje, the vulture narrated its mission. Aje knew so much already because Olodumare had informed her of the mission. She responded to the vulture's request by giving it some cowry shells, which were to be used as medium of exchange. The vulture thanked her, swallowed the cowries to ensure that they were not lost, and traveled back to the waiting crowd (Culled from Falola \& Adebayo, 2000: 41 - 42).

A question assails one's mind. Why was Aje feared so much that no one would want to go near her? Not even members of her own sex: mortal women are timid and fearful to approach their mother and goddess, Aje. She, on her part, is too haughty to receive them into her abode. It is through the effort of the vulture, a bird, which mediates between women and the female goddess of wealth, Aje, that the requests of the market women were granted. These questions can be better analysed in the feminist theory of subjectivity.

The issue and theory of subjectivity is as old as feminism itself. However, it was Freud's theory of subjectivity/sexuality in his postulations on childhood and the Oedipus experience (1963), and Lacan's (1977) reinterpretation of this that elicited an excited and long-drawn array of responses from feminists. Subjectivity can be defined as the culmination or totality of experiences, psychic and physical, which are part of daily living. These experiences are not static. They shift consistently, adding to the growth and maturity of each person. However, the person as a subject or his /her subjectivity can be manipulated by outside forces for good or ill. Subjectivity criticises the social relations of the female to the male, irrespective of the various boundaries that make each woman's experience different from the other. Female subjectivity encapsulates the physical, mental, spiritual, and communal lives of females (Irigaray, 1985; Fuss, 1989). Male and female are subjects, but each person's subjectivity hinges on different interpretations, ideologies and experiences. Men and women experience imposed subjectivities, but of different types, and in varying degrees. The subjectivity of men is mainly positive and empowering in relation to that of women. Men, in conjunction with the apparatuses of the state, expect and demand their personhood from women. They experience their being from an imposed belief system that equates them with positive attributes, albeit at the expense of women (Cixous, 1986; Grosz, 1995). The latter is conditioned and forced to be subservient to the former. This way, her subjectivity is negative in relation to the former. She only enjoys pockets of empowerment when the male decides to let her have it, or when she demands it from fellow women who are inferior to her in social status.

According to Freud (1963), the subjectivity of the female is not whole; it is a castrated subjectivity. To Lacan, female subjectivity is totally subsumed under the male's. The subjectivity of the male is positive in most ramifications. Essentially, therefore, male subjectivity is a self-serving self-imposition.In line with Lacan's theory of subjectivity, women believe the ideology that they are 'naturally' created to be care givers. In reality however, they are subjected beings who unknowingly live out an ideological social formation (Althusser, 1971). Subjectivity is closely intertwined with ideology and sexuality. These three experiences capture in sum the social relations of the female sex to the male sex, irrespective of the different polarities that make each woman's experience unique. Female subjectivity encapsulates the physical, mental, spiritual, and communal lives of the female sex. Literature and literary texts have not only been major avenues in the interplay of difference and subjectivity; they have also produced 'the fused language of class, race and gender' (Davis and Schleifer, 1998). Belsey (1998) argues that fiction, or the text, plays a major role in the construction of subjectivity, especially that of women. Through the text, subjectivities of particular sexes, and their responses are transmitted subtly, and sometimes unconsciously, to the reader. To Fuss, (1989), we bring our social formation and subjectivity into a text in the way we interpret it, the way the author interprets it to us, and the way we interpret it to others. Furthermore, women can be categoriszed into the different subject positions of class, sexuality, nationality, culture, and ethnicity. These positions further highlight the subjectivity of women. 
Literature, according to Althusser (1977), is one of the capitalist apparatuses used in maintaining the status quo by the construction of an ideological subject. Ideology goes beyond mere illusions of reality. It also includes one's relationship to his/her social environment, an environment that has been constructed in such a way as to deny one from seeing 'conditions of existence and the way in which people are socially constituted within them'(Davis and Schleifer, 1998:378).

\section{The Stepmother As the 'Other'}

The subjectivity ascribed to the woman is built on the myth of difference or the 'other'. The label of 'other' connotes a number of negative attributes that have been sustained over the centuries by a patriarchal structure that remains in place because of the status of a particular sex.(Michie, 1989; Minh-ha, 1989; Showalter, 1989). 'Other' reflects a society based on class and difference, for all human beings are not created (biologically or socially) equal. However, within the disempowered class, the group of the 'other', there existmany subdivisions of the 'other', co-existing on a relationship built on inequitable axis. Among this group, the common categories of the 'other' include the avowed spinster, the aged, the barren, the mother of only female children, the stepmother and the mother-in-law.

For the stepmother, she is coming into an environment where she is not entirely welcomed. Her presence, skills and abilities are constantly measured against that of the other wife, wives or departed former wife and mother. For this, she is immediately slammed with the label of the 'Other'. Therefore, she has to work extra hard to earn the acceptance and respect of the children and other relations of the departed other. Every action she takes and every speech she makes are unconsciously made and consistently found to be wanting. By the time the step mother starts to conceive, the response assumes a sustained critical attitude where she will be accused of the sin of partiality, and if she is unable to conceive, she is vigorously vilified and called a witch or a 'she-man'.

It is the latter that the author, Akachi Adimora Ezeigbo, highlights in Roses and Bullets, in the character portrayal of Lizzy, the stepmother of the protagonist, Ginika. Having lost her mother when she was just six years old and her only sibling, her older brother, Nwakire, was nine years old, Ginika's father, Dr. Ubaka Ezeuko, married another woman, Auntie Lizzy. In line with the portrayal of the other, the author uses words and adjectives that labelled Auntie Lizzy as bad and wicked, classic attributes of the average step-mother. The reader first met the stepmother on page 22 of the novel, when she came with her husband, Ubaka, to take Ginika from his brother's home:

Ginika watched, detached. As her stepmother's rather large body pressed against her aunt's, Ginika thought she had gained more weight since she last set eyes on her during the holiday--- She closely observed the three of them and thought how different they were. Auntie Chito was cheerful and homely while her stepmother was sour and bad-tempered,distant and aloof. But her father was neither distant nor aloof.(Emphasis mine).

From the outset therefore, the reader is drawn into a dislike for Auntie Lizzy and the subsequent pages further give more reasons why the dislike should be justified. The comparison made between her and Auntie Chito, Ginika's auntie, is deliberate: Ginika's mother's demise brings to an end a home where there is love and affection, which she cannot get with the presence of the new mother, but which she can get in Auntie Chito's home. True to type, Auntie Lizzy is portrayed as difficult, vain, lazy, materialistic and hard to please. From the moment she stepped into her marital home, she met a wall of hostility from her step children, Ginika and Nwakire, who had decide not to love anyone their remarries to replace their mother. To make matters worse, the author portrayed her as being uninterested in the children and not motherly by nature and attitude:

Ginika blinked in the bright sunlight of instant but distasteful recall. Auntie Lizzy: that was the name she had told them - Nwakire and herself - to call her after she had married their father and taken their dead mother's place.(second emphasis mine) Pp.29.

The name Ginika and Nwakire's stepmother had asked them to address her with sharply contrasts with motherhood. How does she expects them to relate with her as her as a mother when she has already put in place a barrier? The term, Auntie, connotes the characteristics of a sister and a friend, and not that of a mother. This further proved to the children that she was not a mother material. To express their complete disdain of her, we are told that Nwakire, on attaining young adulthood, decided to insult her further by addressing her directly as 'Lizzy', dropping the somewhat respectable appellation, 'Auntie'.

He (Nwakire) called her Lizzy and had done so since he went to university and felt grown up enough to consider it ridiculous to address his stepmother as Auntie Lizzy. He then concluded that it was best to call her by her name and do away with pretension. He recalled the first time he did this, how surprised she had looked and how offended afterwards. But he had stuck to his guns and there was nothing she could do about it. Was it not ridiculous on her part, in the first place, to have asked her stepchildren to call her aunt? Pp. 75 - 76 
It is somewhat odd that their father, who is known to be firm with his children, did not raise an eyebrow at the apparent rudeness of his son to his wife. Perhaps, this is proof that she was just a social appendage in the home, a woman to prevent the widower from feeling lonely. Many instances abound in the novel where we see Auntie Lizzy behaving true to type: a wicked stepmother. Her garishness and outspoken nature, which are her strengths, are used against her to confirm her archetypal status. The few instances afforded her to show that she is not deliberately insensitive to her step children are subsumed under the general label that she is insensitive - when Ginika started her menstruation at the age of thirteen, her father's initial sympathy gave way to stern warnings when he saw her talking with a boy. But it is her stepmother's reaction to this that Ginika took to heart, confirming the subjectivity of the 'Other' woman in her relationship with Auntie Lizzy. The latter had warned her, in her usual brash manner, to be mindful of her friendship with boys, especially in line with the inception of her menstruation: "if you do anything with them, afo ime achaala, pregnancy will come."

But it is stepmother's reaction that Ginika took to heart, and not her father's unfriendly posture:

Ginika squirmed in her seat, hating every word issuing from Auntie Lizzy's mouth, wondering why she and her father should pick on her in this manner. Was this what every girl went through in her home? If her mother were alive, would she treat her the way Auntie Lizzy treated her? Pp. 119 -110.

Auntie Lizzy's subjectivity was further heightened by her inability to bear children, and even though the reader is not told that she grieved over this, for her practical nature and outspokenness hide many things, the author showed how pained she was when she was accused of being barren. It was during her quarrel with Mrs. Ndefo, the wife of Ubaka's friend, who, with her family, had been staying with them because of the war. In the war of words that ensued, one of Mrs Ndefo's children, Amaka, retorted:

Please, don't speak to my mom like that. Is it because you don't have children of your own that you abuse us?

Her kindness and sense of family are hardly remembered. She would welcome Nwakire back home for the holidays from his journeys (page75) or when he came home after he became an officer for the Biafran Army (page 256), prepare family meals (page 107), and in spite of her not liking Philomena, Ginika's friend, still allowed her to spend the weekend with them in the house (pp. $105-107)$, to mention a few.

\section{Mother-in Law vs. Daughter-in-Law}

Merniss (1985), Ezeigbo (1993), and Chukwuma (2004) have discussed the distrust with which women relate to one another, and a common example is the relationship that exists between a mother-in-law and a daughter-in-law. This rivalry can be traced to the conditioning received by the female sex in a patriarchal community: women are brought up not to trust one another, to believe the worst about one another, and to always see the next woman as a "competitor". The typical mother-in-law, therefore, does not see the daughterin-law as family, but rather as a usurper, one who is coming to redirect the son's attention and affection away from the mother. This is especially so if the man in question is the only son. So, from the outset, she goes all out to put the younger woman in her place, which is basically that she is the 'Other', the outsider, a wrong piece in a jigsaw puzzle. Numerous literatureshave described the rivalry as age-long and blames have been levelled against either of the two as the cause.(See Graham, 2010; Apter, 2009; di Giovanni, 2007; Chapman, 2004; Horsley, 1995; 1997; Cocola, 1997).

Sigmund Freud, in his postulations on male and female subjectivity, explains the attachment boy children have for their mothers and why this closeness remains even after the boy's marriage. According to Freud (1961), boys and girls experience painful phases in the formation of their identity and subjectivity. Though they follow different paths, boys and girls suffer pain and loss in order to experience the joys of heterosexuality. The boy child struggles to surmount ignorance, disbelief, fear and pain so as to attain all the masculine attributes needed for his identity. To further illustrates this, Freud patterns this experience on the Oedipus myth documented by Sophocles (494 - 06 BC), about the Greek prince that kills his father and marries his mother out of ignorance. For the male child, his sexual development starts at his mother's breasts. He enjoys his mother's love and attention through breastfeeding. However, he soon comes to realize that his father holds a major share of his mother's love and attention. He becomes jealous and insecure and reaches the emotional stage of planning to get rid of his father in order to claim his mother's undivided attention back on him. While on this quest, he notices that his mother has no penis. In his thinking, since the father controls the sexual affection and attention of his mother, he must have been the one that castrated her. He becomes afraid, believing that his father might castrate him too if he has to struggle with him over his mother. At this juncture, the Oedipus complex comes to a close for the boy. His subjectivity and identity starts from this fear of castration.

According to Freud (1961), it was the realisation that women are castrated that makes the boy's Oedipus complex - the desire to kill his father - to cease. He decides to let go of his mother since she belongs to his father, looks for another non-phallic substitute to transfer his love to, and identifies with his father by accepting his authority over him. This way, his maturity and identity come full circle in a patriarchal society. 
For the girl, her lack of a penis starts the Oedipus complex experience in her. She sees the lack as a punishment for being a girl and she blames her mother for giving birth to her. She develops a penis envy, transferring her love to her father, or, in her inability to get him, to another male. She replaces her penis envy by her wish for a baby from a man. It is this lack of a penis, according to Freud, that causes her to experience a sense of inferiority.

For Freud then, the diagram for his theory of subjectivity/sexuality goes thus:

For the male:

Little boy $\rightarrow$ mother $\rightarrow$ another adult woman

For the female:

Little girl $\rightarrow$ mother $\rightarrow$ father $\rightarrow$ another adult man

Perhaps this explains why men generally uphold and sometimes deify their mother, while the other woman is regarded as a prostitute, a willing sexual object, and a wicked person, a case of 'the Madonna and the whore' (Easthope, 1999:103). The experience of two women in men's life, an encounter that started at childhood, could also explain why men can conveniently marry more than a wife - with some wives, especially the first ones, attaining a 'motherly' status, while subsequent wives fit more into the rebellious, sexual, and wicked mold.

Moreover, mothers tend to be reluctant to severe the emotional attachment they have over their sons, than they do with their daughters. They therefore, relate better with their sons-in-law because there is no feeling of animosity over a usurper taking away the daughter. (Pinker, 1999; Winston, 2004) But mothers sometimes experience a feeling of isolation whenever their sons get married; they feel that the attenetion and affection of the sons, the 'small husbands' would shift to a competitor, younger and more beautiful. But, one might want to ask: what is the basis of comparison?

In Roses and Bullets, Akachi Adimora Ezeigbo depicts the age-old frosty relationship that exists between a mother-in law, Akunnaya Odunze, and her daughter-in-law, Ginika. From Part One of the novel, titled, 'The Beginning', the author shows the fondness with which Akunnaya, has for Eloka, her only son. Being the only son, he was the one that 'lagalised' her marriage, for a woman is nor regarded as being truly married if she has had no male children. Moreover, he is the one that will keep the family name in perpetuity. Eloka's parents therefore, dote on him and regard him as the heir apparent to the rich family fortunes. To his mother, Eloka's 'comfort was her joy and she often acted as if she lived to dote on him.' (p. 123). On page 70, we are given another reason why Akunnaya displays a fondness for her son:

She called him Nna, Father, for he was said to be a reincarnation of her father, his grandfather.

She touched his face lovingly, allowing her hand to slide down his chest.

However, when Eloka married Ginika, his parents welcomed her with joy into their home, and as the new couple was living with them in their house, related with her with the respect given to a good daughter-in-law. Then the Nigerian Civil War started, and Eloka joined the Biafran Army, and Ginika's mother-in-law asked her to come, that she would like to discuss an issue with her. It is at this juncture that the author introduces the ageold rivalry between the two:

She (i.e., Ginika) had to admit that sometimes she felt intimidated by her mother-in-law especially since Eloka left home. He had been a buffer between her and his family, making sure they treated her well. Not that she had anything to complain about really, but sometimes she felt Eloka's mother resented her. (p. 311).

The major cause of rivalry between the two women was on the issue of fertility. Ginika's mother-in-law wanted to know why her daughter-in-law had not taken in, especially since her son had left to join the army. Her worry was that supposed he does not survive the war? She was shocked that Ginika allowed Eloka to join the army without making sure she conceived first. But Ginika couldnot understand her mother-in-law's apprehension. She gave the reason why she was not pregnant yet:

Eloka said he didn't want us to have a baby during the war, that we should wait for it to end and finish our education.

And when Ginika responded in the affirmative that she agreed with the plan, her mother-in-law got really angry at her supposed naivety:

Hei, you quite agree, eh? Lekwenu mиo, look at me-o! Why do people get married? Is it not to have children? Ginika, answer me now? So you married Eloka without nintending to have children, to give him children and grandchildren to me and my husband? Chei! So we came to your father's house to marry you for you to come here and be staring us in the face? So you want to move about in the house empty, ina ekpokoghari ebea? God forbid a bad thing!

From this point, the battle line was drawn between the two women; Akunnaya felt piqued by Ginika's unhurried stance about having children, her grandchildren, while Ginika felt angry over her mother-in-law's interference in her marital affairs. While one may tend not to excuse the younger woman's naivety over the importance of fertility in marriage, especially when the husband has gone off to war, one will not also excuse the aggressive posture of the older woman in broaching the subject. 
Patriarchal society is harsh on women who are barren, those who do not want children because they feel incapable of giving them sufficient attention and time, those who want to delay the time for conception, those who have an obsessional fear of childbirth, and those who have only girl-children (Ogundipe - Leslie, 1987; Okonjo-Ogunyemi, 1996). For some women, their desire to bear children or have grand children is borne out of self-esteem, as children are sites of power for these women. Women become obsessed with having children because of the feelings of achievement, pride, and joy that come with it (Okonjo-Ogunyemi, 1996).

Perhaps, the above explains why Ginika's mother-in-law reacted harshly towards her. She takes it a step further three months after her soldier son, Eloka, had left them again, after a short holiday, for the battlefield. Not observing any pregnancy sign on her daughter-in-law, she asked to speak with her, who confirmed her worst fear: she was still not pregnant. This time, her reaction was harsher:

You have not tried to see things from my point of view, have you? You listen to Eloka and allow him to have his way in this matter. He is a man: what does a man know in matters like this? I'm amazed at your lack of common sense - a woman who is not anxious to have a child for a husband who is a soldier! Do you know tomorrow? Do you know what can happen even in the next minute? And you allow Eloka to go away again without at least attempting to get you pregnant.(Pp. 362).

The consequence of the rivalry was that Ginika was pushed out of her matrimonial home, especially when she became pregnant after she was raped by an acquiatance. The most painful part for her was that she lost the love and respect of her soldier husband, Eloka.

\section{Of Bonding and Empowerment}

The hue and cry that trailed the negative portaryal of women in the media and literary works has given way to a productive response whereby women rewrite history and the portrayal into realistic versions of who women really are. Though women are still regarded as inferior in many instances, they have over the decades refused to heve the image and attitude stay, as they have proven through their skills and contributions to humanity, that these hitherto images that generally castigate their personhood, are not what they are.

Akachi Adimora-Ezeigbo, the author of the novel, Roses and Bullets, gives a realistic account of the different dimensions of realities that exist in the relationship among women living in a patriarchal society, noting that while some women would usually fall into the archetypal pattern prescribed for them, there are also many others that are everyday people: loving, kind, and compassionate. So, her novel is a combination of these two character types. More importantly, she deviates from the temptation of writing a novel that is filled with characters that are all bad and all good. Her characters are well grounded in the community in which they are placed, reflecting the social norms and values of that setting.

To the common saying that women are their own worst enemies, the author presents female characters that prove the inaccuracy of the belief. These characters create the balance needed to prevent the novel from falling into a highly moralistic novel peopled by characters that are either overly good or bad. Two of these characters are Auntie Chito, Ginika's auntie, and Miss Miriam Taylor, Ginaka's Literature in English secondary school teacher. These characters occupied strategic points in the life of the female protagonist; they provided the anchor and support she needed when life's challenges became almost unbearable.

Auntie Chito, the wife of Raymond, Ginika's paternal uncle, acted as a surrogate mother to Ginika throughout the plot of the novel. Having lost her biological mother at the age of six, and not getting the maternal affection and love she craved from her stepmother, Ginika, without much effort, found this in the person of Auntie Chito, who opened her heart and her home to her. The novel opened with the shared camaderie between the two women. The loving familiarity they felt towards each other was abruptly terminated by the arrival of Ginika's father, and her stepmother, Aunt Lizzy. Their unwelcome presence and unfriendly demeanour sharply contrasted with the warmth and affection of the former. For Ginika, the loss she felt at her biological mother's demise was always made up for by the love of Auntie Chito and her family. One of the personal crises Ginika experienced was when she was rapedby a military officer, Lieutenant Ugoro, (pp. 374 -376), and much later, when she was gang raped (pp. 494 -496). Other challenges included her forced eviction from her matrimonial home, and the death of her only sibling, Nwakire, and her husband, Eloka, on the same day. It was the love and support offered her by Auntie Chito and her family that healed her eventually. Therefore, where love and duty mattered, women shatter the mythical belief that they are their own worst enemies, to reach out and help.

Miss Taylor, the missionary teacher, easily falls into the category of the 'Other'.However, her difference was seen in the positive light: she was white, a missionary and a teacher. Her difference attracted her students to her and she had a particular liking to Ginika. When the Civil War started, she had to travel back to England, her homeland, but came after the war to look for Ginika. Her return coincided with one of the crises Ginika was going through: her incarceration and rape by a sergeant. The messianic role she played at Ginika's dire point of need was explitly expressed by Auntie Chito at the end of the novel: 
That teacher of yours is wonderful. She saved your life by coming to Ama-Oyi to look for you when she did. Her supervening presence compelled that Commanding Officer to investigate your abduction by that horrible sergeant. And she saved your too - I was afraid it would be amputated. We learned the sergeant was dismissed from the army. (P. 517)

It is important that the novel started with the bonding that exists between women and also ended with the comforting presence of mostly women, offering companionship and strength to Ginika after her ordeal. Women like Auntie Chito, Miss Taylor, Amaka, and Mrs Ndefo, Amaka's mother, all shatter the archetypal myths of women as wicked, difficult, envious, amongst others. This balance in character portrayal provides one of the high points of the novel.

\section{Bibliography}

[1]. Althusser, Louis. Ideology and Ideological State Apparatuses. In Louis Althusser (Ed.),

[2]. Apter, Terri. What Do You Want From Me? New York: W. W. Norton \& Company Inc., 2009.

[3]. Belsey, Catherine. 'Constructing the Subject: Deconstructing the Text'. Literary Criticism, R.C. Davis and Schleifer (Eds.) New York: Addison Wesley Longman, 1998.

[4]. Chapman, Annie. The Mother-in-Law Dance. Oregon: Harvest House Publishers, 2004.

[5]. Chicago: University of Chicago Press, 1996.

[6]. Cixious, Helene. 1986. 'Sorties.' In Cixous, Helene. and Catherine Clement, The Newly Born Woman, trans. Betsy Wing. Minneapolis, MN: University of Minnesota Press.

[7]. Cocola, Nancy Wasserman. Six in the Bed: Dealing with Parents, In-Laws and Their Impact on Your Marriage. New York: Nerkley Publishing Group, 1997.

[8]. Cornell University Press, 1985.

[9]. Davis, Robert Con. \& Ronald. Schleifer. Literary Criticism. New York: Addison Wesley Longman Inc., 1998.

[10]. Di Giovanni, Janine. "Mothers-in-Law Who Are No Joke.” The Telegraph. 7 December 2007. Web. 7 December 2007.

[11]. Easthope, Anthony. The Unconscious. London: Routledge, 1999.

[12]. Ezeigbo, Theodora Akachi. 'The Enemy Within: Women against Women in Novels by Selected Nigerian Female Writers'. Ihafa A Journal of African Studies, vol. 1, pp. 7-13, 1993.

[13]. Falola, Toyin. \& Akanmu Gafari Adebayo. Culture, Politics and Money among the Yoruba. New Brunswick, USA: Transaction Publishers, 2000.

[14]. Freud, Sigmund. 'Responses to Questions'. Espirit 31 (32); 628-633, 1963

[15]. Fuss, Diana. Essentially Speaking: Feminism, Nature and Difference. New York: Routledge, 1989.

[16]. Graham, Elizabeth. Mothers-in-Law Vs Daughters-in-Law: Let There Be Peace. Kansas City: Beacon Hill Press, 2010.

[17]. Grosz, Elizabeth. 'Psychoanalysis and the Imaginary Body', in Feminist Subjects, Multimedia, Cultural Methodologies. Penny Florence and Reynolds, Dee. (Eds.). Manchester: Manchester University Press, pp. 183-96, 1995.

[18]. Horsley, Gloria. In-Laws: A Guide to Extended Family Therapy. New York: J. Wiley and Sons, 1995.

[19]. Horsley, Gloria. The In-Law Survival Manual: A Guide to Cultivating Healthy In-Law Relationships. New York:: Chichester, Wiley, 1997.

[20]. Ilogu, Edmund. Christianity and Igbo Culture. Enugu: University Publishing Company. 1985.

[21]. Irigaray, Luce. Speculum of the Other Woman. Trans. Gillian C. Gill. Ithaca, N.Y.:

[22]. Koroye, S \& N. Anyadike. Woman in the Academy. Festschrift in Honour of Professor Helen Chukwuma. Port Harcourt: Pearl Publishers, 2004.

[23]. Lacan, Jacques. Ecrits: A Selection, trans. Alan Sheredan. London: Tavistock, 1977.

[24]. Lashgari, Deirdre. (Ed.). Violence, Silence, and Anger: Women's Writing as Trangression. Charlottesville and London: University press of Virginia, 1995.

[25]. Lenin and Philosophy and Other Essays. New York: Monthly Review Press, 1971

[26]. Ogundipe-Leslie, O. 'The Female Writer and her Commitment'. Women in African Literature Today, in Eldred Jones, et al (Eds.). Trenton, N.Y.: African World Press, 1987.

[27]. Okonjo-Ogunyemi, C. African Wo/man Palava: The Nigerian Novel by Women.

[28]. Pinker, Steven. How the Mind Works. New York: W. W. Norton, 1999.

[29]. Winston, Robert. The Human Mind and How to Make the Most of It. New York: Transworld Publishers, 2004. 